\title{
Vibriosis induced by experimental cohabitation in Crassostrea gigas: Evidence of early infection and down-expression of immune- related genes
}

\author{
Sophie De Decker ${ }^{\mathrm{a}}$ and Denis Saulnier ${ }^{\mathrm{a},{ }^{*}}$
}

\author{
a Laboratoire de Génétique et Pathologie, Ifremer, av du Mus de Loup, 17390 La Tremblade, France \\ * Corresponding author: Present address. Laboratoire Biotechnologie et Qualité de la Perle, Centre \\ Océanologique du Pacifique, Ifremer, BP 7004, 98719 Taravao, French Polynesia. Tel.: +33 68954 \\ 60 52; fax: +33 6895460 99, email address : denis.saulnier@ifremer.fr
}

\begin{abstract}
:
The understanding of reciprocal interactions between Crassostrea gigas and Vibrio sp., whether these be virulent or avirulent, is vital for the development of methods to improve the health status of cultured oysters. We describe an original non-invasive experimental infection technique using cohabitation, designed to explore these interactions. Using real-time PCR techniques we examined the dynamics of virulent and avirulent Vibrio sp. in oyster hemolymph and tank seawater, and made a parallel study of the expression of four genes involved in oyster immune defense: $\mathrm{Cg}$-BPI, Cg-EcSOD, Cg-IKB, CgTIMP.
\end{abstract}

No mortality occurred in control animals, but oysters put in cohabitation for 2-48 $\mathrm{h}$ with animals previously infected by two Vibrio pathogens suffered mortalities from 2 to 16 days post-cohabitation. Our results show that virulent Vibrio infect healthy individuals after only $2 \mathrm{~h}$ of cohabitation, with values ranging from $4.5 \times 10^{2}$ to $2 \times 10^{4}$ cells ml $^{-1}$ hemolymph. Simultaneously, an approximate ten-fold increase of the total Vibrio population was observed in control animals, with a 6.6-78.5-fold upexpression of targeted genes. In contrast, oysters exposed to harmful bacteria had mean expression levels strongly down-regulated by a factor of 9.2-29 (depending on the gene) compared with control animals. Although oysters were still found to be infected by virulent Vibrio after $6-48 \mathrm{~h}$ of cohabitation, no significant differences were noted when comparing levels of each transcript in control and infected oysters at the same sampling times during this period: the important differences were noted before $6 \mathrm{~h}$ cohabitation. Taken together, our data support (1) the hypothesis that virulent Vibrio disturbs the immune response of this invertebrate host both rapidly and significantly, although this occurs specifically during an early and transient period during the first $6 \mathrm{~h}$ of cohabitation challenge, and that (2) expression of targeted genes is not correlated with vibriosis resistance.

Keywords: Oyster-Vibrio interactions; Pathogenesis; Immune response; Non-invasive experimental challenge; Real-time PCR 


\section{Introduction}

All organisms are surrounded by harmless and harmful microbes and, as pointed out by Virgin [1], reciprocal interactions during their co-evolution have produced homeostasis between these 'host' organisms and their commensal or pathogenic microbes. Other microbes, in contrast, can be opportunists, which change their status depending on the immune capacity of the host. In Crassostrea sp. oysters, several commensal bacterial species have been found not only in the digestive tract but also in the hemolymph and other soft tissues, probably due to the filter-feeding behaviour of oysters and their open circulatory system [2-5]. The dominant bacteria found in C. gigas hemolymph to date are Gram negative and belong to the genera Vibrio, Pseudomonas, Alteromonas and Aeromonas. Concentrations are normally above $10^{2}$ bacteria per $\mathrm{ml}$, according to estimations made with the classic culture counting method [3]. Such tolerance of commensal bacteria can be explained by a differential response of the oyster immune system to different bacteria. Oyster immune response is mediated via the phagocytic properties of hemocytes and humoral factors and has been seen to vary according to the different bacterial species and strains tested, including some species of concern for human health [5-6]. In the first of these studies, Pruzzo et al. showed that fecal pollutants Escherichia coli and V. cholerae were quickly destroyed by phagocytosis in oyster hemolymph. In contrast, some foodborne pathogens that produce an outer polysaccharide capsule, such as certain strains of $V$. vulnificus, persisted longer in the hemolymph and were seemingly resistant to digestion in hemocyte phagolysosomes, although the mechanism of this resistance is unknown.

Other bacterial species or strains, such as those related to the $V$. splendidus polyphyletic group or to $V$. aestuarianus, have been found to be pathogenic to $C$. gigas oysters in French rearing areas [7-12] and have frequently been identified as part of bacterioplankton communities in the coastal marine environment [13]. These Vibrio species or strains have been shown to be closely associated with mortality events, which occur mainly during the hot season. In such periods, these bacteria are found to be dominant and present in abnormal concentrations up to $10^{4}$ colony forming units per $\mathrm{ml}\left(\mathrm{CFU} \mathrm{m}{ }^{-1}\right)$ hemolymph. These strains were also found to be pathogenic by experimental oyster infection [14]. However, the classical distinction between pathogen and opportunist remains problematic, since impairments of the $C$. gigas defense reaction could occur during natural mortality outbreaks or in experimentally-induced infections. Indeed, De Decker et al. [15] explored certain host susceptibility components to experimentally-induced vibriosis, such as gametogenesis and ploidy using strains of $V$. splendidus and $V$. aestuarianus revealing that reproductive status can affect host susceptibility.

Because oyster cellular defense mechanisms rely mainly on hemocytes, we decided to focus our study on hemocyte-bacterium interactions at a transcriptional level. Four wellcharacterized genes known to be involved in $C$. gigas defense mechanisms were chosen: $C g$-BPI, $C g$-EcSOD, $C g$ - $\mathrm{I} B_{\mathrm{B}}, \mathrm{Cg}$-TIMP. The expression of the $C$. gigas BPI gene (Cg-bpi), encoding a bactericidal-permeability-increasing protein (BPI), is shown to be induced in hemocytes after oyster heat-killed-bacteria challenge, and was detected by in situ hybridization [16]. Cg-EcSOD has been shown to be the major plasmatic multifunctional protein in C. gigas; gene expression and production are restricted to the hemocytes. This protein presumably binds to bacteria and lipopolysaccharide (LPS) and, as it has an unclassical superoxide dismutase (SOD) activity [17-18], could be involved in phagocytic mechanisms [19-21]. A putative $C g$ - $\kappa_{\kappa} B$ protein was chosen that was identified by an

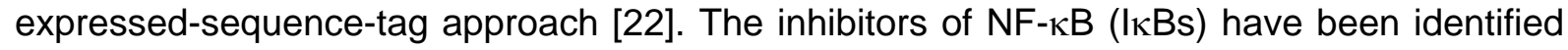
as major components of the Rel/NF-кB signaling pathway, an important mediator of immune responses in vertebrates and insects. $\mathrm{Cg}$-TIMP is an inducible tissue inhibitor of 
metalloproteinase in C. gigas. Its potential role in wound healing and defense mechanisms in this species was illustrated by the induction of $\mathrm{Cg}$-TIMP gene expression in hemocytes following shell damage or non-virulent bacterial challenge [21, 23-24].

To describe the reciprocal interactions between $C$. gigas and virulent or avirulent Vibrio sp. we developed a non-invasive experimental infection technnique of $C$. gigas oysters, using a procedure for horizontal transmission of Vibrio bacteria through cohabitation. Cohabitation trials consisted of placing healthy oysters in the same tank as oysters that had first been experimentally infected or mock infected by injection with virulent Vibrio $\mathrm{sp}$. or sterile artificial seawater, respectively, and sacrificed by severing their adductor muscle at the start (time zero) of cohabitation. The dynamics of both virulent Vibrio sp. and the total Vibrio population in the hemolymph of individual test animals and tank seawater were followed, in parallel with an expression study on the four defense-related hemocytic genes mentioned above, using specially developed real-time PCR techniques.

\section{Material and Methods}

\subsection{Oysters}

Two-year-old diploid oysters (Crassostrea gigas, mean total fresh weight $=4.6 \pm 1.3 \mathrm{~g}$ ) from natural recruitment were collected on a commercial farm (Perquis, Bassin de MarennesOléron, Charente-Maritime, France) and maintained for six months in an indoor infrastructure (Ifremer, La Tremblade), with daily monitoring of oyster mortality. In order to limit the impact of environmental parameters on immune gene expression levels [25][26] similar environmental conditions (see below) and high quality seawater was used for oyster breeding. These oysters were presumed to be healthy because none died during this sixmonth observation period. Since herpesvirus OsHV-1 and $V$. aestuarianus have been identified as the main infectious agents associated with $C$. gigas mortality events in France [27], these oysters were tested for the presence of OsHV-1 infection throughout the cohabitation described below. OsHV-1 DNA was not detected by real-time PCR [28] in tissues of the oyster used in our experiment. These oysters were also tested and found to be free of $V$. aestuarianus DNA at time zero, using a Taqman PCR assay [29].

\subsection{Bacterial strains and culture conditions}

In order to improve virulence towards $C$. gigas for the infection trials and to follow a reproducible experimental procedure [14], the two virulent stains Vibrio splendidus LGP32GFP [30] and V. aestuarianus 02/041 [7] were used together in this study. Both strains were cultured in Marine Broth (Difco), prepared as follows: peptone $4 \%$, yeast extract $1 \%$ diluted in Sterile Artificial Sea Water (SASW $2.3 \% \mathrm{NaCl}, 20 \mathrm{mM} \mathrm{KCl}, 5 \mathrm{mM} \mathrm{MgSO}, 2 \mathrm{mM} \mathrm{CaCl}$ ). Bacteria were grown at $20{ }^{\circ} \mathrm{C}$ for $20 \mathrm{~h}$ under constant shaking. The bacterial culture concentrations were evaluated spectrometrically to obtain an optical density (OD) at $600 \mathrm{~nm}$ wavelength. Cells were centrifuged at $3200 \mathrm{~g}$ for $10 \mathrm{~min}$ and the resulting pellet resuspended in SASW to an OD of two, corresponding to $210^{9} \mathrm{CFU} \mathrm{\textrm {ml } ^ { - 1 }}$. A mix of both bacterial cells $(\mathrm{v} / \mathrm{v})$ was prepared for individual injection.

Both strains, LGP32 [31] and 02/041 (unpublished results) have been completely sequenced. 


\subsection{Experimental infection by intramuscular injection followed by cohabitation}

Oysters were anaesthetised for one to two hours at $20{ }^{\circ} \mathrm{C}$ in a solution of magnesium chloride (28 $\mathrm{g} \mathrm{I}^{-1} \mathrm{MgCl}_{2}$ ), with added phytoplankton (Isochrysis galbata and Chaetoceros calcitrans) and aeration to improve anaesthetic efficiency (personal obsevations). Then, 100 $\mu$ l of a mix of virulent $V$. splendidus LGP32-GFP and $V$. aestuarianus 02/041 bacterial suspensions in equal doses of $10^{8} \mathrm{CFU} \mathrm{ml}{ }^{-1}$, prepared as described in Saulnier et al. [14], were injected into the adductor muscle of oysters. Another group of oysters were injected with SASW (mock infection). After injection, oysters were transferred to tanks filled with 1 $\mu \mathrm{m}$-filtered seawater at $3.1 \%$ salinity, maintained under static conditions at $20{ }^{\circ} \mathrm{C}$ with aeration. Twenty-four hours after these injections, the surviving animals were sacrificed, removing one valve by severing their adductor muscle. The other valve and flesh were used for cohabitation treatments of healthy oysters. Cohabitation was designated as either "control" or "virulent Vibrio". Under both conditions, a ratio of five healthy oysters to one injected was used and total initial density was 5 ind. ${ }^{-1}$. For the control, 30 healthy oysters were put in cohabitation with sacrificed, mock infected, SASW injected oysters. For the "virulent Vibrio" treatment, 200 healthy oysters (referred to as Vibrio infected oysters) were put in cohabitation with sacrificed $V$. splendidus- and $V$. aestuarianus-injected oysters. In both cases the injected oysters also harboured a natural commensal Vibrio flora [3]. After 48 hours of cohabitation, all injected oysters were removed and the tank seawater was replaced with $1 \mu \mathrm{m}$-filtered UV-treated seawater at $3.1 \%$ salinity. All experiments were performed under static water conditions at $20{ }^{\circ} \mathrm{C}$ with aeration, but no supplementary food. During the cohabitation and post-cohabitation periods, groups of oysters were sampled from the main cohabitation tanks and used for mortality monitoring, bacterial assessments and gene expression study. These samples were taken at $2 \mathrm{~h}, 6 \mathrm{~h}, 8 \mathrm{~h}, 24 \mathrm{~h}$ and $48 \mathrm{~h}$ of cohabitation and at days 7 and 19 of the post-cohabitation period. At each sampling, ten oysters from the virulent Vibrio treatment were randomly selected for mortality monitoring, rinsed with UVtreated seawater and transferred into individual small aquaria containing UV-treated seawater.

\subsection{Hemolymph, oyster soft tissues and water sampling}

Oysters are surrounded by waterborne microorganisms. To circumvent or at least minimize contamination during tissue sampling, hemolymph withdrawal from the adductor muscle was performed immediately after removing seawater from the palleal cavity, using a syringe fitted with a 23-gauge needle. Individual samples of hemolymph were collected from live oysters from both the control ( $n=3$ control oysters) and the virulent Vibrio tanks $(n=9$ Vibrio infected oysters), at the different sampling times during the cohabitation and post cohabitation phases of the experiment. The flesh of each oyster was severed from its shell using a scalpel and stored individually at $-20^{\circ} \mathrm{C}$. One $\mathrm{ml}$ of seawater was also collected from each tank at each time point $(2 \mathrm{~h}, 6 \mathrm{~h}, 8 \mathrm{~h}, 24 \mathrm{~h}$ and $48 \mathrm{~h}$ for cohabitation; days 7 and 19 post-cohabitation) and stored at $-80^{\circ} \mathrm{C}$.

\subsection{Bacterial quantification by real-time PCR}

\subsubsection{DNA extraction procedures}

Individual samples of hemolymph $(200 \mu \mathrm{l})$ and tank seawater $(500 \mu \mathrm{l})$ were centrifuged at $10000 \mathrm{~g}$ for 5 minutes. DNA was extracted from cell pellets using QIAmp DNA Mini Kit (Qiagen), following manufacturer's instructions. The same DNA extraction procedure was followed using $20 \mathrm{mg}$ of oyster tissues collected from different separated organs. Pelleted 
DNA was resuspended in $200 \mu \mathrm{l}$ ultra pure water and DNA yields and their purity determined spectrometrically (Eppendorf). DNA extracts were stored at $-20{ }^{\circ} \mathrm{C}$ until use.

\subsubsection{Real-time $P C R$ assay analyses}

Three real-time PCR assays were used for the specific detection and quantification of the $V$. splendidus LGP32-GFP strain, for bacteria related to $V$. aestuarianus and the Vibrio genus overall, targeting the GFP, dnaJ and 16S rRNA genes, respectively. The GFP-qPCR test was developed for this study using Taqman chemistry and the same PCR conditions as those used for $V$. aestuarianus qPCR detection [29]. The sequences of oligonucleotides and Taqman probes used here are shown in Table 1. They were assessed for species-specificity using a BLAST search to determine homology with known sequences. For the detection and quantification of bacteria related to the Vibrio genus, we used the qPCR protocol described by Thompson et al. [32], with slight modifications for the quantification of amplicons by SYBR green chemistry. Each PCR assay was run in duplicate in a final volume of $25 \mu$ containing 5 $\mu$ I DNA sample, $200 \mathrm{nM}$ of each primer (Table 1) and $12.5 \mu \mathrm{l} 2 \times$ Brilliant II SYBR® Green QPCR Master Mix (Stratagene). Thermal cycling consisted of an initial denaturation step at $95{ }^{\circ} \mathrm{C}$ for $10 \mathrm{~min}$ followed by 40 cycles of denaturation at $95{ }^{\circ} \mathrm{C}$ for $10 \mathrm{~s}$, annealing and extension at $65^{\circ} \mathrm{C}$ for $30 \mathrm{~s}$. Lastly, the amplicon melting temperature curve was analysed over one cycle at $95{ }^{\circ} \mathrm{C}$ for $30 \mathrm{~s}, 55^{\circ} \mathrm{C}$ for $30 \mathrm{~s}$ and $95{ }^{\circ} \mathrm{C}$ for $30 \mathrm{~s}$. A real-time PCR assay was conducted on a MX3000 Thermocycler (Stratagene) and fluorescence intensity was expressed in delta reporters (dR) after background subtraction. The threshold was set using an amplification based algorithm from the MX3000 software (Stratagene) for the initial plate. For the other plates we used an interplate calibrator to set the threshold manually. Threshold Cycle (Ct) value corresponded to the PCR cycle number at which an increase in reporter fluorescence above the baseline signal was first detected.

Standard curves for the detection of LGP32-GFP and bacteria related to the Vibrio genus were established using 1:10 serial dilutions of DNA extracted from $V$. splendidus LGP32GFP strain and $V$. aestuarianus 02/041 strain. All DNA concentrations used for Vibrio genus quantification were artificially spiked in DNA extracted from $10^{6}$ cells $\mathrm{ml}^{-1}$ Photobacterium phosphoreum reference strain. The quantification of bacterial cells by real-time PCR was compared with the enumeration of the bacterial cells used for DNA extractions, using a Malassez counting chamber under a light microscope.

\subsection{Analysis of gene expression in hemolymph by real-time PCR}

\subsubsection{Hemocyte RNA extraction procedures}

Total RNA was isolated from individual hemolymph samples $(600 \mu \mathrm{l})$ and centrifuged at 800 $\mathrm{g}$ for 5 min using a commercial RNA purification kit (RNeasy Mini Kit, Qiagen) including a DNAse treatment. RNA concentrations in each sample were estimated using the Quant-It ${ }^{\mathrm{TM}}$ Ribogreen ${ }^{\circledR}$ reagent and RNA standard curves (Stratagene), reading the plates on a Stratagene MX3000 thermal cycler. The quality of extracted RNA was checked by agarose gel electrophoresis using 20 randomly selected RNA samples and verified to be free of DNA contamination by performing a no reverse transcription assay in real time qPCR expression analysis (see paragraph below).

\subsubsection{Real-time PCR analysis of gene expression}

The expression levels of four different mRNA transcripts, Cg-BPI, Cg-EcSOD, Cg-I B and $\mathrm{Cg}$-TIMP, were determined by real-time PCR on a MX3000 Thermocycler (Stratagene). An elongation factor encoded by the ef I gene was used to provide a steady-state expression 
level of a house-keeping gene, allowing an internal control for gene expression as described in previous work done with the mollusks C. gigas and Mya arenaria [20-21, 23, 30, 33-34]. Approximately $100 \mathrm{ng}$ of individually-isolated RNA transcripts were reverse-transcribed in a final volume of $20 \mu \mathrm{l}$, using an optimized blend of oligo-dT and random primers (Qiagen) and a mix of two reverse transcriptases (Quantiscript Reverse Transcriptase, Qiagen) according to the manufacturer's instructions (Quantitect Reverse Transcription Kit, Qiagen). cDNAs were amplified by real-time PCR using specific primers designed by Primer 3 software, choosing general conditions of $60+/-1{ }^{\circ} \mathrm{C}$ optimal annealing temperature for pairs of oligonucleotides, and an amplicon size under $300 \mathrm{bp}$ (Table 2). The cDNA conserved regions for primer design were deduced from GenBank-available targeted sequence alignment. The primers were checked for specificity using a BLAST search to determine homology with known sequences. Two to three primer pairs per gene were tested for their efficacy and specificity in real-time PCR, leading to the selection of a primer pair for the subsequent gene expression analysis done in this study. The real-time PCR assay was performed in duplicate in a total volume of $25 \mu \mathrm{L}$, using the Brilliant SYBR Green QPCR master mix (Stratagene), with $200 \mathrm{nM}$ of each primer. The thermal cycle was performed with a two-step PCR: one cycle at $95^{\circ} \mathrm{C}$ for 10 min followed by 40 cycles at $95^{\circ} \mathrm{C}$ for $30 \mathrm{~s}, 60^{\circ} \mathrm{C}$ for $60 \mathrm{~s}$ and $72{ }^{\circ} \mathrm{C}$ for $60 \mathrm{~s}$, and ending with one cycle at $95^{\circ} \mathrm{C}$ for $60 \mathrm{~s}, 60^{\circ} \mathrm{C}$ for $30 \mathrm{~s}$ and $95^{\circ} \mathrm{C}$ for $30 \mathrm{~s}$, aimed at melting temperature curve analysis. All fluorescence thresholds for the first and consecutive PCR plates were set as indicated above for bacteria quantification by qPCR, using CDNAs prepared from the pool of hemocytes collected at time zero as an interplate calibrator. PCR efficiencies $\left(E=10^{(-1 / \text { llope })}\right.$ ) and linear regressions were calculated by drawing standard curves from a serial dilution analysis of these cDNAs, testing each dilution in triplicate.

The calculation of relative mRNA levels was based on the comparative Ct method [35] modified by Pfaffl [36]. The fold change Qr in the target gene, normalized to the ef I gene and relative to expression at time zero using a pool of 11 cDNAs obtained from 11 hemolymph samples collected at T0 (just before the beginning of cohabitation trial) was expressed for each sample as $\mathrm{Qr}=\left[\left(\mathrm{E}_{\text {target }}\right)^{\Delta \mathrm{Ct}}{ }_{\text {target }}{ }^{\text {(pool T0 }- \text { sample TX) }}\right] /\left[\left(\mathrm{E}_{\text {eff }}\right)^{\Delta \mathrm{Ct}}\right.$ efl $\left.^{\text {(pool T0 - sample Tx) }}\right]$.

This calculation was performed on all individual samples of cDNAs collected from both control oysters ( $n=3$ at each time point) and Vibrio-infected oysters ( $n=9$ at each time point).

\subsection{Statistical analysis}

To analyse the degree of linear relationships i) between virulent Vibrio quantifications in tank water and in hemolymph of individual oysters and ii) between total Vibrio population quantifications in tank water and in hemolymph of individual oysters, at the same time point, Pearson's correlations were calculated (XLSTAT-Pro). Difference in ef I Ct individual means between control and virulent Vibrio treatments was tested using a Bonferroni test [20]. The ratio changes (mean Qr control/mean Qr Vibrio) of defense-associated gene transcripts were tested for significant differences between control and virulent Vibrio oysters at the same point in time during the experiment and between two consecutive sampling times for the same batch of oysters, using unpaired Student's t tests (XLSTAT-Pro). A Pearson's correlation test was performed in order to evaluate for each virulent Vibrio infected oysters a relationship between virulent Vibrio load in hemolymph and the ratio changes (Qr Vibrio) of each targeted defense-associated gene transcripts. 


\section{Results}

\subsection{Oyster mortality monitoring}

No mortality of control oysters occurred during experimentation. In the virulent Vibrio cohabitation tank, in contrast, dead oysters were removed daily. Mortality was monitored in the batches of ten randomly-chosen oysters taken from the virulent Vibrio tank at the different sampling times during and post cohabitation. These oysters were individualized in order to avoid potential post cohabitation infection by neighboring dying oysters. Similar results were observed at all time points (data not shown): oyster mortality started and peaked at day two, and ended at day 16. After day 16, there was no more mortality until the end of the survey at day 25. Two hours of cohabitation was sufficient to cause significant mortality in test oysters, with 5 dead oysters out of 10 at day 14 . Overall, $27 \%$ of the 70 animals transferred in individual aquaria died during the 16 days of mortality that occurred during this trial.

\subsection{Detection and quantification of the total Vibrio population and the two virulent} Vibrio strains

Specific PCR primers and a Taqman probe were designed in order to provide relevant diagnostic tools for this study. These tools can be used to target and quantify the gene encoding for the Green Fluorescent Protein of a mutated LGP32-GFP strain, which is related to $V$. splendidus and pathogenic for $C$. gigas. Linear values for PCR amplification were obtained for 1:10 dilutions of purified LGP32-GFP DNA corresponding to $1.210^{3}$ to $1.210^{9}$ cells of LGP32-GFP ml ${ }^{-1}$, with 0.993 correlation and $99.5 \%$ PCR efficacy (Fig. 1). Size of amplified PCR products was verified by visualizing the expected 194-bp long amplicon (not shown) after agarose gel electrophoresis.

Similarly, the PCR primers described by Thompson et al. [32] to quantify the total Vibrio population were evaluated using real-time PCR based on SYBR Green chemistry. The same dilution ranges of LGP32-GFP DNA and purified $V$. aestuarianus 02/041 DNA as above were

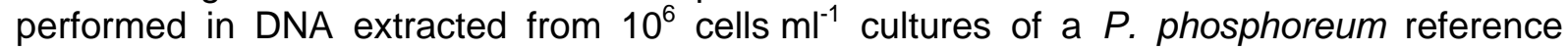
strain. Dissociation curve analysis revealed that a single amplicon was obtained for all dilutions, with melting temperatures of $81.9{ }^{\circ} \mathrm{C}$ and $82.5{ }^{\circ} \mathrm{C}$ for LGP32-GFP and 02/041 strains respectively. Both quantification curves were similar, exhibiting correlations of $r^{2}=$ 0.997 and 0.976 and $\mathrm{PCR}$ reaction efficacies of $99 \%$ and $96 \%$, respectively, when dilutions of LGP32-GFP and 02/041 strains ranged from $1.110^{8}$ to $1.110^{2}$ cells $\mathrm{ml}^{-1}$ (data not shown). Adding exogenous DNA from a phylogenetically-close bacterial strain unrelated to the Vibrio genus had no influence on PCR-cycle threshold values, regardless of the LGP32-GFP and 02/041 DNA concentrations used. Treatment of $\mathrm{Ct}$ values collectively yielded a single quantification curve with 0.992 correlation and $95 \%$ PCR efficacy (Fig. 2).

The quantification of the total Vibrio population in the tank water used in cohabitation trials revealed high concentrations of $0.910^{4}$ and $1.110^{4}$ cells ml $^{-1}$ in control and virulent Vibrio treatments respectively at time zero (Fig. 3A). This population increased by a factor of two in the control tank as early as two hours from the start of cohabitation, and later stabilized at approximately $310^{4}$ cells $\mathrm{ml}^{-1}$, strongly suggesting that the total Vibrio population issued from the injected sacrificed oysters was released into the tank seawater. Bacterial increase reached a factor of 20 in the virulent Vibrio tank seawater and later stabilized at approximately $310^{5} \mathrm{cells} \mathrm{ml}^{-1}$. Individual assessments of the bacterial strains used showed both LGP32-GFP and 02/041 at high concentrations in the tank seawater two hours following the start of the cohabitation challenge, at $310^{3}$ and $210^{4}$ cells mll $^{-1}$, respectively. A slight decrease or increase depending on strain was then observed in the water between 8 and 24 
hours post cohabitation. After having replaced the tank seawater at the end of cohabitation time (48 h), a significant decrease in the total Vibrio population was noticed at day seven in both tanks. At this time, LGP32-GFP was nearly undetectable, whereas 02/041 could still be found in the tank water.

Mean total Vibrio population quantification in the hemolymph of oysters from the control tank increased from $2.6 \pm 110^{4}$ to $1.7 \pm 2.910^{5}$ cells ml$^{-1}$ in the first two hours of cohabitation and at six hours (Fig. 3B), already returned to lower value of $10^{4}$ cells $\mathrm{ml}^{-1}$. In contrast, virulent Vibrio were found to infect almost all of the tested oysters very quickly, with concentrations in the hemolymph increasing from a undetectable level at time zero, to $5 \pm 8.910^{2}$ or $7 \pm$ $6.810^{3}$ cells $\mathrm{ml}^{-1}$ for $V$. splendidus LGP32-GFP and $V$. aestuarianus 02/041, respectively, after only two hours of cohabitation. Furthermore, virulent Vibrio were detected at concentrations ranging from $3.610^{2}$ to $1.0410^{6}$ cells $^{-1}$ in the different oyster organs that were tested separately, including gills, mantle, labial palps and digestive gland. After a slight increase of $V$. aestuarianus 02/041 and decrease of $V$. splendidus LGP32-GFP strains in oyster hemolymph during the 48 hours of cohabitation, all tested animals were found to be negative for $V$. splendidus LGP32-GFP at day seven and for both strains by day 19 .

A positive correlation (Pearson's $r=0.745, p=0.005$ ) was found between the mean

logarithmic load of total Vibrio in the hemolymph $(n=13)$ and in the tank seawater $(n=13)$ sampled from T0 to day seven. A similar positive correlation (Pearson's $r=0.445, p=0.004$ ) was found between 02/041 and LGP32-GFP, analyzing hemolymph taken from 40 individual oysters sampled during the first $48 \mathrm{~h}$ of cohabitation.

\subsection{Monitoring the expression of genes involved in defense reactions}

The expression of four selected genes, known from the literature to be involved in defense reactions mediated by hemocytes, was analyzed by real-time PCR to examine their pattern of expression during the course of the trial in control or Vibrio infected oysters. In a preliminary step, the efficacy of qPCR for all targeted genes, including the elongation factor gene and its ability to generate a single GPCR amplicon, were evaluated using a 1:5 serial dilution of a pool of cDNA transcripts obtained from the 11 samples of hemolymph collected at time zero and dissociation curve analysis. Efficiencies for $\mathrm{Cg}$-BPI, $\mathrm{Cg}$-EcSOD, Cg-IкB, CgTIMP and ef I genes were $104.7 \%, 102.3 \%, 105.6 \%, 105.6 \%$ and $95.9 \%$, respectively. For all genes studied, the square regression correlation coefficient of detection ranged between 0.95 and 0.99 . Dissociation curve analysis revealed that a single amplicon was obtained for all genes studied, with melting temperatures of $81^{\circ} \mathrm{C}, 80^{\circ} \mathrm{C}, 82{ }^{\circ} \mathrm{C}, 82{ }^{\circ} \mathrm{C}$ and $76{ }^{\circ} \mathrm{C}$ respectively. The specificity of $\mathrm{QPCR}$ was further verified by agarose gel electrophoresis of qPCR products, visualising as expected one amplicon of the attempted size calculated upon the gene sequence data available on GenBank (not shown).

The detected amount of the housekeeping gene elongation factor mRNA did not show significant difference between control and Vibrio-infected animals ( $p$-value $>0.05$ ), with mean threshold values and standard errors of $18.8 \pm 2.2$ and $19.9 \pm 1.8$, respectively $(n=48$ individual RNA samples). The relative expression ratio of immune genes could thus be estimated by normalizing against the ef I gene. A significant up-regulation of the four targeted genes was observed after normalization, especially for Cg-EcSOD, in each of the three oysters from the control tank two hours after cohabitation (Fig. 4). Transcript levels for $\mathrm{Cg}$ TIMP, Cg-BPI, Cg-ІкB and Cg-EcSOD genes were 6.6, 9.7, 15.9 and 78.5 fold greater, respectively, than their expression at time zero. In contrast, the mean relative transcript levels of genes from the nine Vibrio-infected oysters were approximately ten fold lower compared to expression in control animals, with values ranging from 0.11 (corresponding to 
a 9.2-fold down-regulation) for $\mathrm{Cg}$-TIMP gene to 0.03 (corresponding to a 29 -fold downregulation) for the $\mathrm{Cg}$-BPI gene. Thereafter, no significant differences were observed between control and virulent Vibrio-infected oysters (Fig. 4). Noticeably, low levels of $\mathrm{Cg}$ TIMP transcripts were reported in both treatments at $24 \mathrm{~h}$ and $48 \mathrm{~h}$ post-cohabitation, with a decrease in values ranging from 0.25 to 0.13 (corresponding to a down-regulation from a factor of 4 to 7.7). Whatever the considered defense-associated gene tested, no correlation (Pearson's $p>0.05$ ) was found between the logarithm load of each virulent Vibrio and the ratio changes (Qr Vibrio) of transcripts, analyzing hemolymph taken from 40 individual oysters sampled during the first $48 \mathrm{~h}$ of cohabitation.

\section{Discussion}

Oyster production represents the majority of the aquaculture industry in France, with the dominant species $C$. gigas grown in a near monoculture. This situation has arisen from the evolution of the French oyster industry from traditional harvesting of wild beds to very intensive cultures. The high rearing densities of French $C$. gigas cultures are favored by the settlement behavior of oysters occurring when swimming larvae reach metamorphosis. In addition, the presence of large populations of wild oysters and other filter-feeding mollusks leads to high trophic competition, which may pose difficulties for the management of rearing sites and impair oyster health status [27]. Indeed, exceptional mortality rates of $40 \%$ have been regularly reported in young cultured $C$. gigas oysters over the past decade or more, occurring mainly during spring and summer seasons in France. Classically, the professional oyster breeders cope with these mortalities by increasing the numbers of these, less costly, young oysters (i.e. spat) in their rearing systems. Amongst pathogens found in close association with these mortality events reported in France, two Vibrio species, $V$. splendidus and $V$. aestuarianus, were found (saulnier et al, 2010). We therefore focused our study on cohabitation experiments using these Vibrio species, purposely choosing a non-invasive method of infection to explore the possibility of horizontal transfer of these Vibrio from diseased to healthy oysters. A pathogenesis study was undertaken to describe the pathway of virulent and avirulent Vibrio, quantifying them in oyster hemolymph and tank water, while quantifying transcripts of well-characterized hemocytic genes involved in host response, ranging from tissue damage repair to recognition and degradation of pathogenic bacteria.

Litle data is available on non-invasive experimental infection methods for mollusks, although experimental vibriosis was conducted by Travers et al [37] and Gay et al. [8] using balneation and cohabitation procedures in abalone Haliotis tuberculata and $C$. gigas respectively. Indeed, experimental vibriosis was recently induced in $C$. gigas infected by bath challenge using only mature and spawning animals (De Decker et al, 2010). Nevertheless this procedure exhibit poor repeatability in mortality rates. The same authors highlighted the importance of sexual maturity for vibriosis infection processes. In the same way we cannot exclude also that in vitro cultivation of virulent bacterial strains using synthetic medium may change their virulence, an inconvenient that cohabitation procedure should avoid. Regarding oysters, other non-invasive experimental infection assays have been described using a virus (OsHV-1) in larvae [38], and parasites such as Bonamia ostreae and Perkinsus spp. [39-40]. The present article relates the development of the first experimental infection technique targeted at better understanding the early steps of pathogenesis events in adult $C$. gigas. We obtained the first evidence of successful experimental horizontal transfer of vibriosis in four independent preliminary cohabitation assays. Significant mortality rates were seen in oysters in the virulent Vibrio treatment, whereas no mortality was observed by contact of healthy oysters with oysters that had been injected with sterile artificial seawater injected (mock infected). All moribund animals collected and tested during these preliminary assays harbored a high concentration of the challenge Vibrio in their hemolymph, as shown by the 
classic plate-counting method. This protocol aimed at mimicking oyster death caused in the wild by disease, predator attack, natural death or resulting from bad zootechnical practices.

The use of real-time PCR in microbial diagnostics is a valuable alternative to time-consuming traditional methods such as classical bacteriological analysis based on the cultivability of organisms. Although based on the detection of DNA and not on the culture of live organisms, this molecular biology-based technique offers multiple advantages during surveys. Notably, its specificity and sensitivity allow the detection and quantification of low concentrations of epidemiologically significant microbial agents in aquatic animals and their environment [29, 41-44]. In the present study, development and evaluation were made of a Taqman real-time PCR to detect a mutated $V$. splendidus LGP32 strain tagged with GFP, known to be pathogenic for $C$. gigas oyster by experimental injection. This particular strain was chosen to overcome the risk of detection and quantification of other strains of avirulent $V$. splendidus present in the background flora of oysters $[8,14]$.

Our technique successfully produced a rapid and heavy infection $\left(>510^{3}\right.$ cells $\left.\mathrm{ml}^{-1}\right)$ in all test oysters in the virulent Vibrio treatment. Vibrio from the injected oysters were detected in the hemolymph and organs of the healthy test oysters after just two hours of cohabitation. At this time an approximate ten-fold increase of the total Vibrio population was also observed in the hemolymph of healthy oysters in the control treatment in cohabitation with mock-infected specimens coinciding with its slight increase in control tank water. Because no mortality was observed in these control oysters suffering an increase of Vibrio population in their hemolymph, we considered that oysters experienced a challenge with avirulent Vibrio. Strong individual variations in bacterial load were also reported during the first $48 \mathrm{~h}$ of the post cohabitation challenge, suggesting that individual oysters have different susceptibility levels to vibriosis under this mode of infection. Such variability could be related, in part, to the high genetic variability of this mollusk species [45]. Nevertheless the level of $V$. aestuarianus infection was highly correlated $(p<0.01)$ with that of $V$. splendidus LGP32-GFP, strengthening the hypothesis of a potential inter-strain collaboration previously suggested after experimental injection challenges [14]. Our study of the dynamics of detection of Vibrio DNA in tank water revealed that avirulent and virulent Vibrio were both transmitted horizontally via a waterborne mode of action, probably facilitated by the open circulatory system of this mollusk species as well as its filter feeding. Importantly, Vibrio bacterial loads were found to be correlated between the hemolymph of control oysters and the tank water $(p$ $<0.01$ ). It is also notable that 7 and 19 days after the $48 \mathrm{~h}$ cohabitation trial, no detectable levels of $V$. splendidus LGP32-GFP or $V$. aestuarianus DNA, respectively, were found in the hemolymph of survivors of the virulent Vibrio cohabitation, supporting the hypothesis that some oysters succeeded in recovering from infection due to efficient defense mechanisms, even if potential presence of Vibrio in other tissues or organs cannot be excluded. The contrasting level of natural Vibrio flora supports the hypothesis that the oyster immune system might distinguish between virulent and avirulent, potentially beneficial, Vibrio species. Natural background Vibrio persisted at a level of $110^{4}$ cells ml-1 during this 19-day survey, despite the use of UV-treated seawater. A qualitative characterization of this flora by classical bacteriological methods, coupled with metagenomics or by other molecular typing approaches will open new perspectives for a better comprehension of the mechanisms involved in defense reactions, leading to either tolerance or destruction of invading bacteria [46-47].

In an attempt to characterize host-Vibrio interactions, the second aim of our study was to evaluate the kinetics of immune-related gene expression in the oyster $C$. gigas in response to virulent or avirulent Vibrio sp.. Our non-invasive experimental infection technique aimed at reproducing horizontal transfer of vibriosis to healthy oysters. For mollusk bivalves and $C$. gigas in particular, most studies reported in the literature have used a form of immune 
stimulation based on a treatment by inactivated microorganisms, mainly Micrococcus luteus, $V$. splendidus, V. anguillarum, V. alginolyticus, V. tubiashii, V. metschnikovii [16, 23, 48-49], or microbial components such as lipopolysaccharides poly I:C, poly G:C and dsDNA [48, 5051], with the main purpose of confirming the involvement of newly identified putative immune genes in defense reactions and studying them at a transcriptional level. These studies and some others used live bacteria, which were mostly harmless strains of Micrococcus luteus, $V$. alginolyticus, $V$. tasmaniensis, $V$. anguillarum, $V$. splendidus, $V$. tubiashii and $V$. metschnikovii [20, 23-24, 33, 52-53]. To our knowledge, $V$. aestuarianus is the only virulent organism tested in juvenile $C$. gigas that has been seen to induce a significant downexpression of $\mathrm{Cg}$-EcSOD transcripts by 3.6 and 8.3 fold, on days one and three post injection challenge, respectively, compared with controls [21]. In this last experiment, relative $\mathrm{Cg}$ TIMP expression remained stable for the duration of the trial in both Vibrio-injected and control animals [21]. Nevertheless, the experimental infection procedure used remains problematic because the intramuscular injection of pathogen at high dose $\left(510^{7} \mathrm{CFU}\right.$ oyster ${ }^{1}$ ) could have both short-circuited some potentially important first line immune defenses or activation systems and disturbed normal host immune response against undesirable invaders. In this study, live virulent bacteria were used for the first time in a non-invasive challenge method for $C$. gigas immune gene expression monitoring. The same individual hemolymph samples used for the Vibrio kinetics investigation were also used for RNA extractions and real-time PCR quantification of four immune-related target genes and a housekeeping control gene extensively used in previous studies [20-21, 23, 33, 52, 54-55]. Our results on control animals are in agreement with those reported in the above studies: the use of non-pathogenic bacterial strains induced an up-expression of most of the studied immune genes. In this study, an increase of the total Vibrio population found in control animals after two hours of cohabitation coincided with a significant up-regulation of the four targeted genes $C g$-BPI, $C g$-EcSOD, $C g$-I $\kappa B$ and $C g$-TIMP $(p<0.001)$, with expression value increases ranging from 6.6 to 78.5 fold depending on the targeted gene. This significant upexpression was remarkable for its intensity in comparison with data reported in the literature $[16,18,19,21]$ but only transient, since it was not observed after six hours post cohabitation. Conversely, despite the variability recorded in individual response, all targeted transcripts tended to be down-regulated at a later stage, after being normalized. The use of virulent Vibrio species i.e. V. splendidus and $V$. aestuarianus caused a significant $(p<0.001)$ decrease of expression levels in all studied genes, ranging from a 9.2 to a 29 -fold decline, depending on the gene, compared to expression levels in control animals, two hours after the start of cohabitation. These results suggest that virulent Vibrio highly disturbed the immune response, which might be understood as a strategy of pathogenic Vibrio, aimed at enhancing their colonization skills into the $C$. gigas host. Nevertheless, this apparent immunodepression, occurring less than six hours after the start of the cohabitation challenge, was short-term and no significant differences $(p>0.05)$ were later observed when comparing levels of each transcript in control and infected oysters at the same sampling time, with the noticeable exception of $\mathrm{Cg}-\mathrm{I} \mathrm{KB}$ gene at $48 \mathrm{~h}$. None of the expression levels of the targeted genes were correlated with $V$. splendidus and $V$. aetuarianus bacteremia in this study, suggesting that expression of these genes is not correlated withvibriosis resistance.

\section{Conclusion}

We present a preliminary study on Vibrio infection levels and expression patterns of immunerelated genes following cohabitation of $C$. gigas with oysters harboring commensal or virulent Vibrio. Our results show that in contrast to avirulent Vibrio, which induces significant upexpression of four targeted immune related genes, virulent Vibrio depress the immune response of this invertebrate host both rapidly and significantly. This disturbance is an early and transient state occurring during the first six hours challenge with pathogenic Vibrio. The original horizontal method mimicks natural vibriosis and the development of molecular tools 
designed to characterize pathogenesis open up possibilities for identifying new genes involved in disease resistance and virulence of Vibrio. Research could be developed in this direction combining our new non-invasive infection method with other high-throughput methods such as microarrays. Such approaches would permit the simultaneous analysis of expression profiles of multiple $C$. gigas and virulent bacterial genes made available by expressed sequenced tag approaches [56] and whole genome sequencing of Vibrio species pathogenic for oysters.

\section{Acknowledgments}

We thank N. Faury for providing the primer sequences used in this study to quantify of C. gigas ef 1 mRNA. The LGP32-GFP strain was supplied by F. Le Roux to whom we are grateful. The authors would also like to thank P. Haffner and N. Soussi for their technical support and C. Blanvillain, H. McCombie, R.M. Le Deuff, C. François and Y. Reynaud for their kind help during rewriting of the manuscript.

\section{References}

1. Virgin HWS. In vivo veritas: pathogenesis of infection as it actually happens. Nat Immunol. 2007 8:1143.

2. Murchelano RA, Bishop JL. Bacteriological study of laboratory-reared juvenile American oysters (Crassostrea virginica). J Invertebr Pathol. 1969 14:321.

3. Olafsen JA, Mikkelsen HV, Giæver HM, Høvik Hansen G. Indigenous bacteria in hemolymph and tissues of marine bivalves at low temperatures. Appl Environ Microbiol. 1993 59:1848-54.

4. Colwell RR, Liston J. Microbiology of shellfish. Bacteriological study of the natural flora of Pacific oysters (Crassostrea gigas). Appl Microbiol. 1960 8:104-9.

5. Pruzzo C, Gallo G, Canesi L. Persistence of vibrios in marine bivalves: the role of interactions with haemolymph components. Environ Microbiol. 2005 7:761-72.

6. Harris-Young L, Tamplin ML, Mason JW, Aldrich HC, Jackson JK. Viability of Vibrio vulnificus in Association with Hemocytes of the American Oyster (Crassostrea virginica). Appl Environ Microbiol. 1995 61:52-7.

7. Garnier M, Labreuche Y, Garcia C, Robert M, Nicolas JL. Evidence for the involvement of pathogenic bacteria in summer mortalities of the Pacific oyster Crassostrea gigas. Microb Ecol. 2007 53:187-96.

8. Gay M, Berthe FC, Le Roux F. Screening of Vibrio isolates to develop an experimental infection model in the Pacific oyster Crassostrea gigas. Dis Aquat Org. 2004 59:49-56.

9. Gay M, Renault T, Pons AM, Le Roux F. Two Vibrio splendidus related strains collaborate to kill Crassostrea gigas: taxonomy and host alterations. Dis Aquat Org. 2004 62:65-74.

10. Lacoste A, Jalabert F, Malham S, Cueff A, Gelebart F, Cordevant C, et al. A Vibrio splendidus strain is associated with summer mortality of juvenile oysters Crassostrea gigas in the Bay of Morlaix (North Brittany, France). Dis Aquat Org. 2001 46:139-45.

11. Le Roux F, Gay M, Lambert C, Waechter M, Poubalanne S, Chollet B, et al. Comparative analysis of Vibrio splendidus-related strains isolated during Crassostrea gigas mortality events. Aquat Living Resour. 2002 15:251-8.

12. Waechter M, Le Roux F, Nicolas JL, Marissal E, Berthe F. Characterization of pathogenic bacteria of the cupped oyster Crassostrea gigas. C R Biologies. 2002 325:231-8.

13. Thompson JR, Pacocha S, Pharino C, Klepac-Ceraj V, Hunt DE, Benoit J, et al. Genotypic diversity within a natural coastal bacterioplankton population. Science. 2005 307:1311-3. 
14. Saulnier D, De Decker S, Haffner P, Cobret L, Robert M, Garcia C. A large-scale epidemiological study to identify bacteria pathogenic to Pacific oyster Crassostrea gigas and correlation between virulence and metalloprotease-like activity. Microb Ecol. 2010 59:787-98. 15. De Decker S, Normand J, Saulnier D, Pernet F, Castagnet S, Boudry P. Responses of diploid and triploid Pacific oysters Crassostrea gigas to Vibrio infection in relation to their reproductive status. J Invertebr Pathol. in press.

16. Gonzalez M, Gueguen Y, Destoumieux-Garzon D, Romestand B, Fievet J, Pugniere $M$, et al. Evidence of a bactericidal permeability increasing protein in an invertebrate, the Crassostrea gigas Cg-BPI. Proc Natl Acad Sci USA. 2007 144:17759-64.

17. Green TJ, Dixon TJ, Devic E, Adlard RD, Barnes AC. Differential expression of genes encoding anti-oxidant enzymes in Sydney rock oysters, Saccostrea glomerata (Gould) selected for disease resistance. Fish \& Shellfish Immunology. 2009 26:799-810.

18. Scotti PD, Dearing SC, Greenwood DR. Characterisation of cavortin, the major haemolymph protein of the Pacific oyster $<i>($ Crassostrea gigas $)</ i>$. New Zealand Journal of Marine and Freshwater Research. 2007 41:91 - 101.

19. Gonzalez M, Romestand B, Fievet J, Huvet A, Lebart M-C, Gueguen Y, et al. Evidence in oyster of a plasma extracellular superoxide dismutase which binds LPS. Biochem Biophys Res Commun. 2005 338:1089-97.

20. Huvet A, Herpin A, Dégremont L, Labreuche $Y$, Samain J-F, Cunningham C. The identification of genes from the oyster Crassostrea gigas that are differentially expressed in progeny exhibiting opposed susceptibility to summer mortality. Gene. 2004 343:211-20.

21. Labreuche Y, Lambert C, Soudant P, Boulo V, Huvet A, Nicolas JL. Cellular and molecular hemocyte responses of the Pacific oyster, Crassostrea gigas, following bacterial infection with Vibrio aestuarianus strain 01/32. Microbes Infect. 2006 8:2715-24.

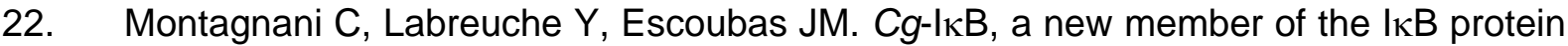
family characterized in the pacific oyster Crassostrea gigas. Dev Comp Immunol. 2008 32:182-90.

23. Montagnani C, Avarre JC, de Lorgeril J, Quiquand M, Boulo V, Escoubas JM. First evidence of the activation of Cg-timp, an immune response component of Pacific oysters, through a damage-associated molecular pattern pathway. Dev Comp Immunol. 2007 31:111.

24. Montagnani C, Le Roux F, Berthe F, Escoubas J-M. Cg-TIMP, an inducible tissue inhibitor of metalloproteinase from the Pacific oyster Crassostrea gigas with a potential role in wound healing and defense mechanisms. FEBS Letters. 2001 500:64-70.

25. Gagnaire B, Gay M, Huvet A, Daniel J-Y, Saulnier D, Renault T. Combination of a pesticide exposure and a bacterial challenge: In vivo effects on immune response of Pacific oyster, Crassostrea gigas (Thunberg). Aquatic Toxicology. 2007 84:92-102.

26. Green T, Barnes A. Reduced salinity, but not estuarine acidification, is a cause of immune-suppression in the Sydney rock oyster Saccostrea glomerata. Marine Ecology Progress Series. 2010 402:161-70.

27. Miossec L, Le Deuff R, Goulletquer P. Alien species alert : Crassostrea gigas (Pacific oyster). ICES Cooperative Research Report. 2009 299:42.

28. Pépin JF, Riou A, Renault T. Rapid and sensitive detection of ostreid herpesvirus 1 in oyster samples by real-time PCR. J Virol Methods. 2008 149:269-76.

29. Saulnier D, De Decker S, Haffner P. Real-time PCR assay for rapid detection and quantification of Vibrio aestuarianus in oyster and seawater: A useful tool for epidemiologic studies. J Microbiol Methods. 2009 77:191-7.

30. Mateo DR, Greenwood SJ, Araya MT, Berthe FCJ, Johnson GR, Siah A. Differential gene expression of $\mathrm{y}$-actin, Toll-like receptor 2 (TLR-2) and interleukin-1 receptor-associated kinase 4 (IRAK-4) in Mya arenaria haemocytes induced by in vivo infections with two Vibrio splendidus strains. Dev Comp Immunol. 2010 34:710-4.

31. Le Roux F, Mohamed Z, Chakroun N, Binesse J, Saulnier D, Bouchier C, et al. Genome sequence of Vibrio splendidus: an abundant planctonic marine species with a large genotypic diversity. Environ Microbiol. 2009 11:1959-70. 
32. Thompson JR, Randa MA, Marcelino LA, Tomita-Mitchell A, Lim E, Polz MF. Diversity and dynamics of a north atlantic coastal Vibrio community. Appl Environ Microbiol. 2004 70:4103-10.

33. Gueguen Y, Cadoret J-P, Flament D, Barreau-Roumiguiere C, Girardot A-L, Garnier $\mathrm{J}$, et al. Immune gene discovery by expressed sequence tags generated from hemocytes of the bacteria-challenged oyster, Crassostrea gigas. Gene. 2003 303:139-45.

34. Taris N, Lang R, Camara M. Sequence polymorphism can produce serious artefacts in real-time PCR assays: hard lessons from Pacific oysters. BMC Genomics. 2008 9:234.

35. Livak KJ, Schmittgen TD. Analysis of Relative Gene Expression Data Using RealTime Quantitative PCR and the 2- $\Delta \Delta C T$ Method. Methods. 2001 25:402-8.

36. Pfaffl MW. A new mathematical model for relative quantification in real-time RT-PCR. Nucl Acids Res. 2001 29:e45-.

37. Travers M-A, Basuyaux O, Le Goic N, Huchette S, Nicolas J-L, Koken M, et al. Influence of temperature and spawning effort on Haliotis tuberculata mortalities caused by Vibrio harveyi: an example of emerging vibriosis linked to global warming. Glob Chang Biol. 2008 15:1365-76.

38. Le Deuff R, Nicolas JL, Renault T, Cochennec N. Experimental transmission of herpes-like virus to axenic larvae of Pacific oyster, Crassostrea gigas. Bull Eur Assoc Fish Pathol. 1994 142:69-72.

39. Lallias D, Arzul I, Heurtebise S, Ferrand S, Chollet B, Robert M, et al. Bonamia ostreae-induced mortalities in one-year old European flat oysters Ostrea edulis: experimental infection by cohabitation challenge. Aquat Living Resour. 2008 21:423-39.

40. Schott EJ, Fernandez-Robledo JA, Alavi MR, Vasta GR. Susceptibility of Crassostrea ariakensis (Fujita 1913) to Bonamia and Perkinsus spp. infections: Potential for disease transmission between Oyster species. J Shellfish Res. 2008 27:541-9.

41. Pang L, Zhang XH, Zhong Y, Chen J, Li Y, Austin B. Identification of Vibrio harveyi using PCR amplification of the toxR gene. Lett Appl Microbiol. 2006 43:249-55.

42. Goarant C, Merien F. Quantification of Vibrio penaeicida, the etiological agent of Syndrome 93 in New Caledonian shrimp, by real-time PCR using SYBR Green I chemistry. J Microbiol Methods. 2006 67:27.

43. Gilad O, Yun S, Zagmutt-Vergara F, Leutenegger C, Bercovier H, Hedrick R. Concentrations of a Koi herpesvirus (KHV) in tissues of experimentally infected Cyprinus carpio koi as assessed by real-time TaqMan PCR. Dis Aquat Org. 2004 60:179-87.

44. Goarant C, Reynaud Y, Ansquer D, De Decker S, Merien F. Sequence polymorphism-based identification and quantification of Vibrio nigripulchritudo at the species and subspecies level targeting an emerging pathogen for cultured shrimp in New Caledonia. J Microbiol Methods. 2007 70:30-8.

45. Taris N, Sauvage C, Batista FM, Baron S, Ernande B, Haffray P, et al. Conséquences génétiques de la production de larves d'huîtres en écloserie : étude des processus de dérive et de sélection. Les Actes du BRG. 2006 6:521-41.

46. Sansonetti PJ, Medzhitov R. Learning Tolerance while Fighting Ignorance. Cell. 2009 138:416-20.

47. Vance RE, Isberg RR, Portnoy DA. Patterns of Pathogenesis: Discrimination of Pathogenic and Nonpathogenic Microbes by the Innate Immune System. Cell Host \& Microbe. 2009 6:10-21.

48. Green TJ, Barnes AC. Inhibitor of REL/NF-KB is regulated in Sydney rock oysters in response to specific double-stranded RNA and Vibrio alginolyticus, but the major immune anti-oxidants EcSOD and Prx6 are non-inducible. Fish Shellfish Immunol. 2009 27:260-5.

49. Mitta G, Vandenbulcke F, Hubert F, Roch P. Mussel defensins are synthesised and processed in granulocytes then released into the plasma after bacterial challenge. J Cell Sci. 1999 112:4233-42.

50. Zhang D, Jiang S, Qiu L, Su T, Wu K, Li Y, et al. Molecular characterization and expression analysis of the IkB gene from pearl oyster Pinctada fucata. Fish Shellfish Immunol. 2009 26:84-90. 
51. Pallavicini A, del Mar Costa M, Gestal C, Dreos R, Figueras A, Venier P, et al. High sequence variability of myticin transcripts in hemocytes of immune-stimulated mussels suggests ancient host-pathogen interactions. Developmental \& Comparative Immunology. 2008 32:213-26.

52. Tirape A, Bacque C, Brizard R, Vandenbulcke F, Boulo V. Expression of immunerelated genes in the oyster Crassostrea gigas during ontogenesis. Dev Comp Immunol. 2007 31:859-73.

53. Bao Y, Li L, Xu F, Zhang G. Intracellular copper/zinc superoxide dismutase from bay scallop Argopecten irradians: Its gene structure, mRNA expression and recombinant protein. Fish Shellfish Immunol. 2009 27:210-20.

54. Montagnani C, Kappler C, Reichhart JM, Escoubas JM. Cg-Rel, the first Rel/NF-KB homolog characterized in a mollusk, the Pacific oyster Crassostrea gigas. FEBS Letters. 2004 561:75-82.

55. Roberts S, Goetz G, White S, Goetz F. Analysis of Genes Isolated from Plated Hemocytes of the Pacific Oyster, Crassostreas gigas. Mar Biotechnol. 2009 11:24-44.

56. Fleury E, Huvet A, Lelong C, de Lorgeril J, Boulo V, Gueguen Y, et al. Generation and analysis of a 29,745 unique Expressed Sequence Tags from the Pacific oyster (Crassostrea gigas) assembled into a publicly accessible database: the GigasDatabase. BMC Genomics. 2009 10:341.

\section{Tables}

\section{Table 1}

Nucleotide sequences, melting temperature $(\mathrm{Tm})$ and qPCR efficiency of primers and probes used in Taqman and SYBR Green real-time PCR assays.

Table 1

\begin{tabular}{|c|c|c|c|c|}
\hline Name & Sequence $\left(5^{\prime}-3^{\prime}\right)$ and flurochromes & $\begin{array}{c}\text { qPCR } \\
\text { efficienc } \\
\text { y (\%) }\end{array}$ & $\begin{array}{l}\mathrm{Tm} \\
\left({ }^{\circ} \mathrm{C}\right)\end{array}$ & Ref. \\
\hline GFP-F & TCAGTGGAGAGGGTGAAGGT & 99.5 & 60 & This study \\
\hline$G F P-R$ & TACATAACCTTCGGGCATGG & & 61 & This study \\
\hline GFP probe & Cy5- TGTTCCATGGCCAACACTTGTCA -BHQ1 & & 68 & This study \\
\hline $\begin{array}{l}\text { DNAj aes } \\
\text { F1 }\end{array}$ & GTATGAAATTTTAACTGACCCACAA & 98 & 58 & $\begin{array}{l}\text { (Saulnier et } \\
\text { al, 2009) }\end{array}$ \\
\hline $\begin{array}{l}\text { DNAj aes } \\
\mathrm{R} 1\end{array}$ & CAATTTCTTTCGAACAACCAC & & 59 & $\begin{array}{l}\text { (Saulnier et } \\
\text { al, 2009) }\end{array}$ \\
\hline DNAj probe & $\begin{array}{l}\text { Texas Red-TGGTAGCGCAGACTTCGGCGAC- } \\
\text { BHQ2 }\end{array}$ & & 71 & $\begin{array}{c}\text { (Saulnier et } \\
\text { al, 2009) }\end{array}$ \\
\hline $567 \mathrm{~F}$ & GGCGTAAAGCGCATGCAGGT & 95 & 64 & $\begin{array}{l}\text { (Thompson } \\
\text { et al., 2004) }\end{array}$ \\
\hline $680 \mathrm{R}$ & GAAATTCTACСССССТCTACAG & & 66 & $\begin{array}{l}\text { (Thompson } \\
\text { et al., 2004) }\end{array}$ \\
\hline
\end{tabular}




\section{Table 2}

Primers paired used and amplification efficiency of primer sets in real time qPCR expression analysis.

Table 2

\begin{tabular}{|c|c|c|c|c|}
\hline $\begin{array}{l}\text { Targeted } \\
\text { Genes }\end{array}$ & $\begin{array}{l}\text { Primers } \\
\text { name }\end{array}$ & $\begin{array}{l}\text { Oligonucleotide sequences } \\
\qquad\left(5^{\prime}-3^{\prime}\right)\end{array}$ & $\begin{array}{c}\text { qPCR } \\
\text { efficiency } \\
(\%)\end{array}$ & $\begin{array}{l}\text { Amplicon } \\
\text { length (bp) }\end{array}$ \\
\hline Cg-ef1 & $\begin{array}{l}\text { EFF } \\
\text { EFR }\end{array}$ & $\begin{array}{l}\text { AGTCACCAAGGCTGCACAGAAAG } \\
\text { TCCGACGTATTTCTTTGCGATGT }\end{array}$ & 95.9 & 199 \\
\hline Cg-BPI & $\begin{array}{l}\text { S-BPI1F } \\
\text { S-BPI1R }\end{array}$ & $\begin{array}{l}\text { TGACGTCAGCCCAATGTAAG } \\
\text { ACTGCTGGGCTTTGTGAACT }\end{array}$ & 104.7 & 200 \\
\hline $\mathrm{Cg}-$ & S-SOD2F & CGAGATGGAACCAAACCACT & & \\
\hline EcSOD & $\begin{array}{l}\text { S- } \\
\text { SOD2R }\end{array}$ & GACGTTGAAACCGGTCAGAT & 102.3 & 124 \\
\hline$C g-I_{\kappa} \mathrm{B}$ & $\begin{array}{l}\text { S-IKB3F } \\
\text { S-IKB3R }\end{array}$ & $\begin{array}{l}\text { TCCAGACCCCTCTTCATTTG } \\
\text { CAGGGCGATATCGTCATACC }\end{array}$ & 105.6 & 152 \\
\hline Cg-TIMP & $\begin{array}{l}\text { S- } \\
\text { TIMP1F } \\
\text { S- } \\
\text { TIMP1R }\end{array}$ & $\begin{array}{l}\text { TGGTGTTGACCGTTCTCTGT } \\
\text { AGAACCCAGCAGAGATGACC }\end{array}$ & 105.6 & 227 \\
\hline
\end{tabular}

\section{Figures}

Fig. 1 


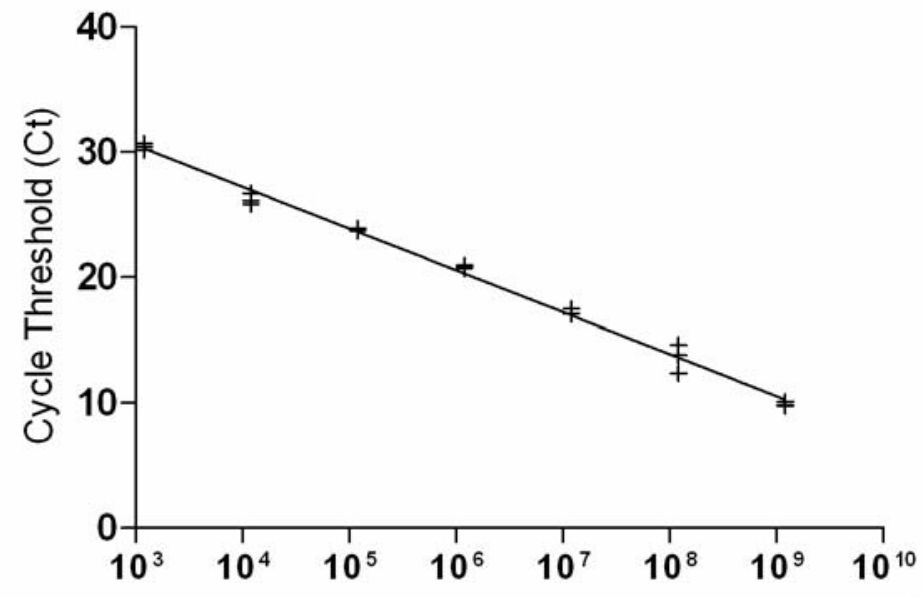

Log cell numbers of $V$. splendidus LGP32-GFP.ml ${ }^{-1}$

Standard curve for $V$. splendidus LGP32-GFP real-time PCR in 1:10 serial dilutions of purified LGP32-GFP DNA, corresponding to $1.210^{3}$ to $1.210^{9}$ cells of LGP32-GFP $\mathrm{ml}^{-1}$. Standard curves were generated by plotting the log cell number on the mean threshold cycle (Ct) value obtained from triplicate assays. The linear regression, represented here was obtained by collectively treating all the data; $r^{2}=0.993$; PCR reaction efficacy was $99.5 \%$.

Fig. 2

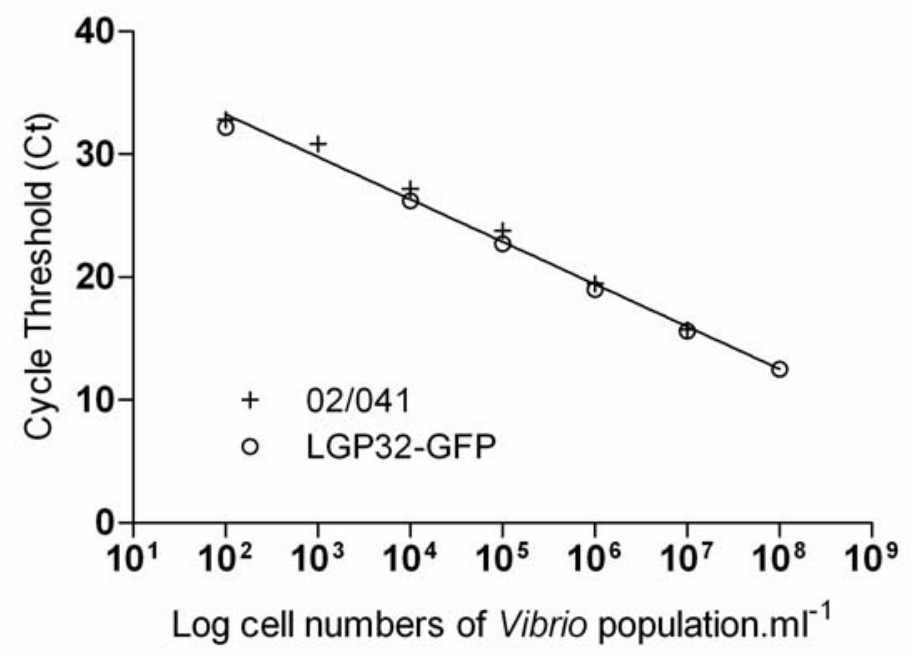

Standard curve for total Vibrio population real-time PCR in 1:10 dilutions of purified LGP32GFP $(+)$ and $V$. aestuarianus 02/041 DNA (०) done in DNA extracted from $10^{6}$ cells $\mathrm{ml}^{-1}$ of $P$. phosphoreum reference strains. Standard curves were generated by plotting the log cell number versus the mean threshold cycle $(\mathrm{Ct})$ value obtained from triplicate assays. A single linear regression, represented here, was obtained by collectively treating all the data; $r^{2}=$ 0.992; PCR reaction efficacy was $95 \%$. 
Fig. 3

A

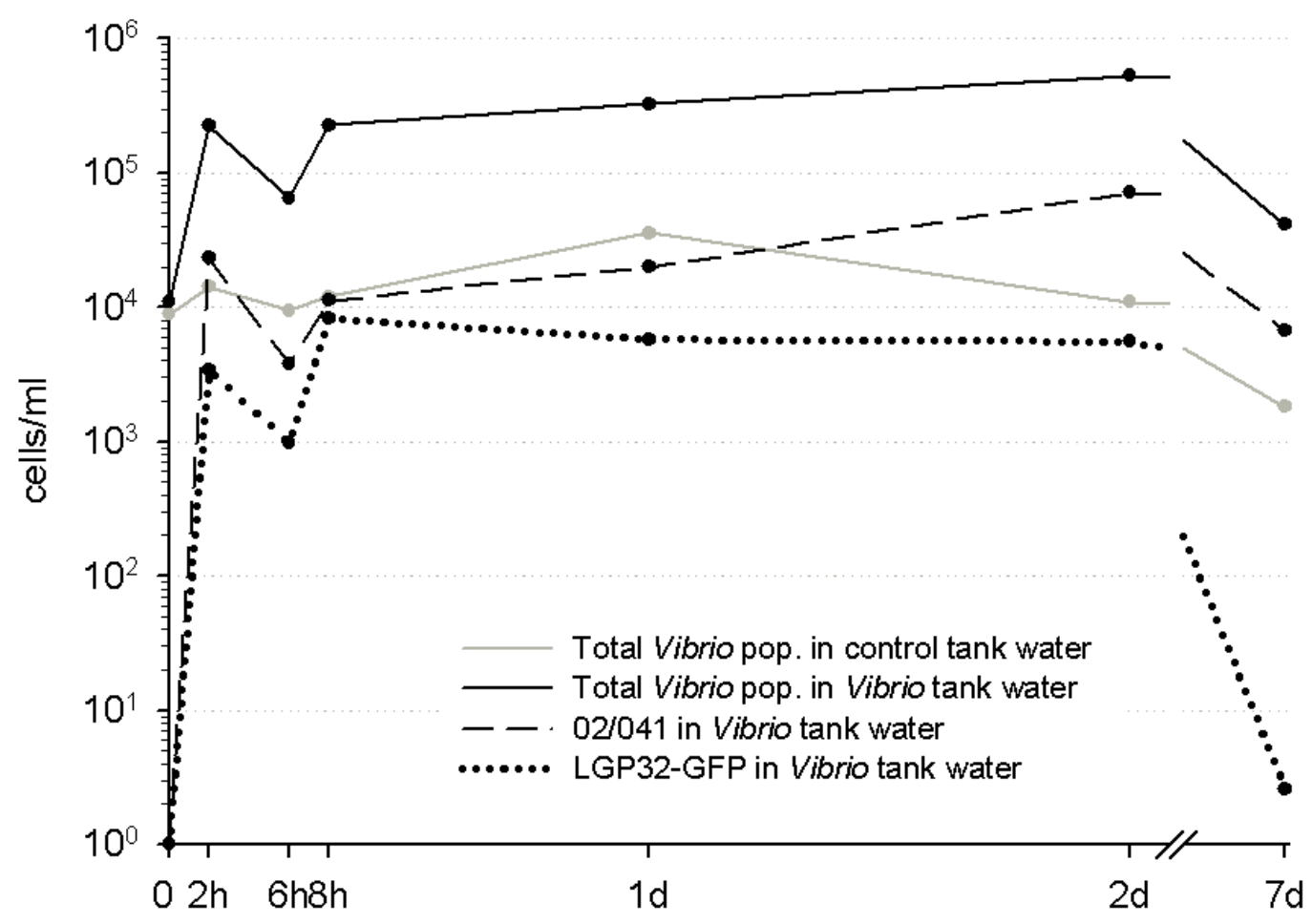

B

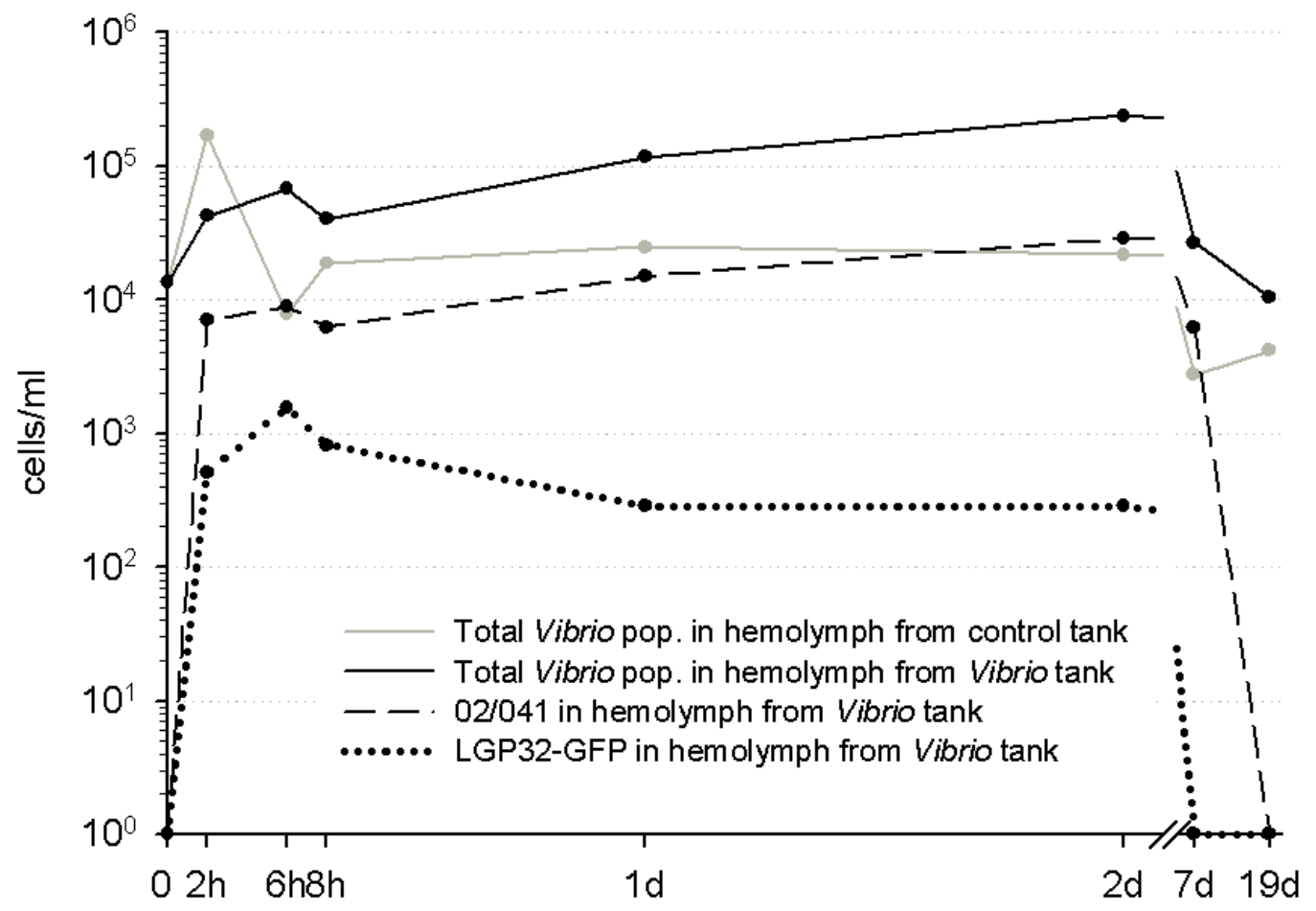


Kinetics of the total Vibrio population and the two virulent LGP32-GFP \& 02/041 Vibrio strains quantified by qPCR in seawater (A) or hemolymph (B) of both control and virulent Vibrio tanks from T0 to day 7. Limit of detection for total Vibrio, LGP32-GFP and 02/041 was $10^{2}$ cells $\mathrm{ml}^{-1}$ for all the quantification assays corresponding to 2-3 cells/well. Mean values obtained from individual hemolymph samples collected from control oysters $(n=3$ for each time point) and Vibrio infected oysters ( $n=9$ for each time point) were plotted. No LGP32GFP or $V$. aestuarianus DNA was detected in any samples collected from the control tank.

Fig. 4
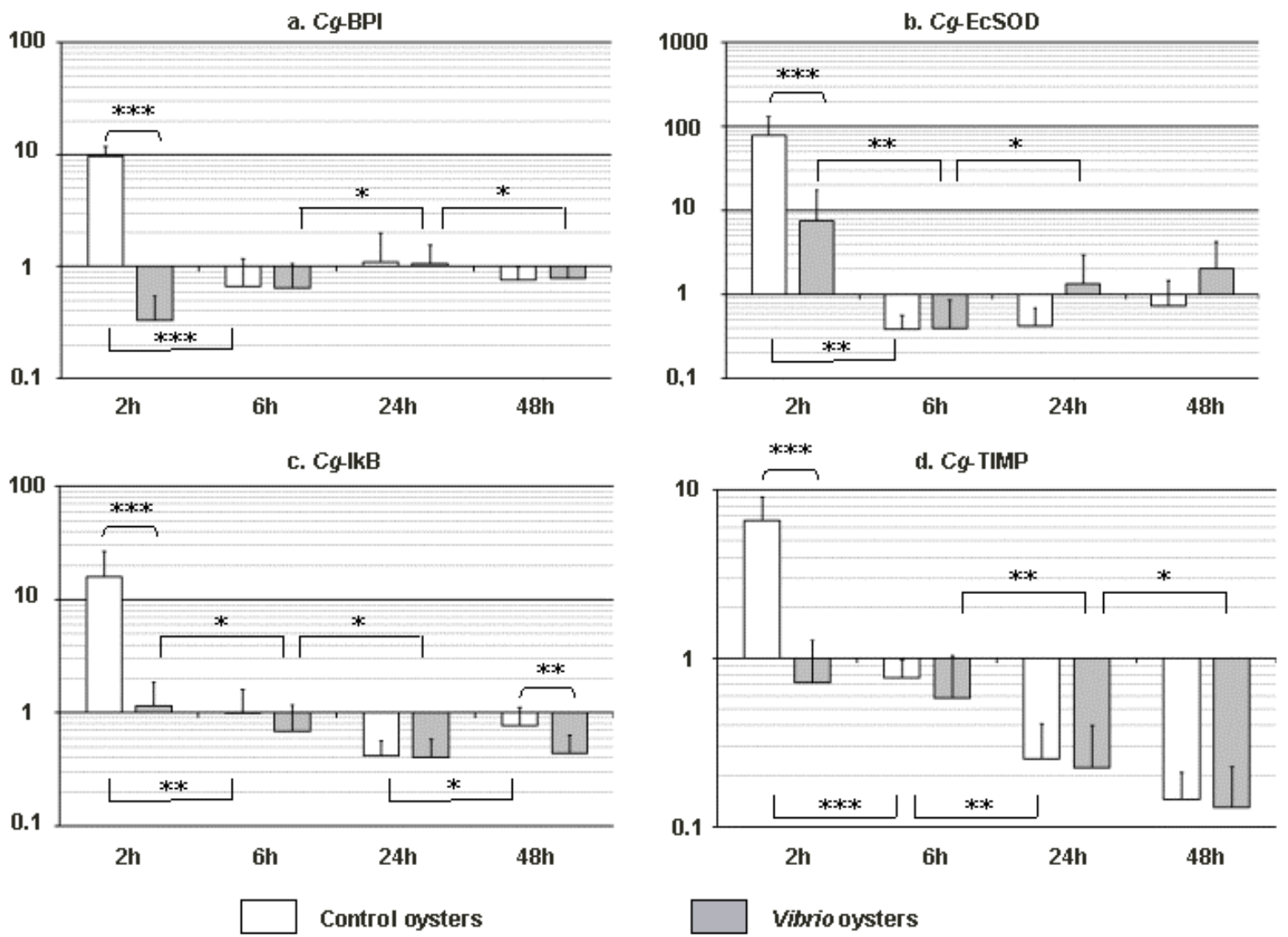

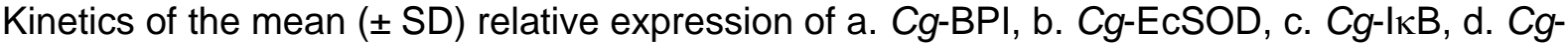
TIMP in hemolymph sampled in control $(n=3)$ and Vibrio infected oysters $(n=9)$. Standard bars correspond to integrated technical and individual variability. Gene expression is normalized to the ef I gene and relative to expression at time zero. Asterisks indicate a significant difference in expression levels between control and Vibrio infected oysters or between two consecutive sampling times ( ${ }^{*} p<0.05 ; * *$ : $\left.p<0.01 ; * \star *: p<0.0001\right)$. 